\title{
Intercrops improve the drought resistance of young rubber trees
}

\author{
Cathy Clermont-Dauphin ${ }^{1,2}$ (D) Chaiyanam Dissataporn ${ }^{2} \cdot$ Nopmanee Suvannang $^{2} \cdot$ Pirach Pongwichian $^{2}$. \\ Jean-luc Maeght ${ }^{3}$. Claude Hammecker ${ }^{1,2} \cdot$ Christophe Jourdan $^{1}$
}

Accepted: 19 September 2018 / Published online: 22 October 2018

(C) INRA and Springer-Verlag France SAS, part of Springer Nature 2018

\begin{abstract}
The expansion of rubber cultivation into drought prone areas calls for innovative management to increase the drought resistance of the trees. The competition for water exerted by an intercrop in the upper soil layers will likely stimulate the growth of young rubber tree roots into deeper soil layers where water availability is more stable. This study examined the effects of a legume (Pueraria phaseoloides) and a grass (Vetiveria zizanoides) intercrop, on the fine root traits of young rubber trees (Hevea brasiliensis Müll. Arg.) established along a toposequence covering a range of soil depths in northeast Thailand. Two plots with and without the intercrops were set up in a 3-year-old rubber plantation. Tree girth, mortality rate, nutrient content in the leaves, predawn leaf water potential, and soil water content profiles were monitored over four successive years. Fine root length density, specific root length, fine root biomass, and fine root diameter of the rubber trees were measured in the fourth year. In shallow soils, the trees with the legume intercrop had a higher growth rate, a higher leaf nutrient content, and a higher fine root length density in the deepest soil layers than the controls, supporting the hypothesis of an adaptive root response, increasing drought resistance. However, the trees with the grass intercrop did not show this effect. In deep soils, specific root length was highest without the intercrops, and the soil water profile and predawn leaf water potential suggested that trees with intercrops benefited from increased water extraction below $110 \mathrm{~cm}$ depth. We showed, for the first time, that rubber tree root traits can be manipulated through intercropping to improve drought resistance. However, our results suggest intercropping might not reduce risks of tree mortality caused by drought in the shallowest soils of the subhumid area of northeast Thailand.
\end{abstract}

Keywords Hevea brasiliensis · Pueraria phaseoloides · Vetiveria zizanoides · Intercrop · FRLD · SRL · Predawn leaf water potential $\cdot$ Soil water profile $\cdot$ Soil depth $\cdot$ Agroforestry $\cdot$ Northeast Thailand

\section{Introduction}

Rubber tree cultivation (Hevea brasiliensis Müll. Arg.) is a major economic activity of South-East Asia and is expanding rapidly into areas with low and unreliable rainfall. This makes

Cathy Clermont-Dauphin cathy.clermont@ird.fr

1 UMR 210 Eco\&Sols (IRD, INRA, CIRAD, Supagro Montpellier, Univ. Montpellier), 2 Place Viala, 34060 Montpellier, France

2 Land Development Department, Ministry of Agriculture and Co-Operative, Phaholyothin Road, Chatuchak, Bangkok 10900, Thailand

3 UMR 242 Institute of Ecology and Environmental Sciences -Paris (IRD,UPCM, CNRS, INRA,Univ. Paris-Diderot, UPEC), Soils and Fertilisers Research Institute, Hanoi, Vietnam it necessary to develop agricultural management techniques to reduce the effects of droughts, particularly during the immature phase of the tree. Changing the tree root architecture using intercrops has been suggested as one way of achieving this (Forey et al. 2017; Kaye and Quemada 2017; Schroth 1999). However, while the effects of intercrops on rubber tree growth have received considerable attention (Broughton 1977; Clermont-Dauphin et al. 2016; Delabarre 1998), their effects on the tree root architecture and the drought resistance of the trees have been less documented.

A tree root system is generally described in terms of two groups of roots with different morphologies and sizes. The division between these two groups is based on their diameter, with an artificial but conventional limit of $2.0 \mathrm{~mm}$ (Persson 1983). One group, made up of medium and coarse roots, with a diameter greater than $2.0 \mathrm{~mm}$, is responsible for anchoring the tree to the soil (Crook and Ennos 1998) and for transporting water from the deep soil horizon 
(Schenk and Jackson 2002). The other group is made up by fine roots with diameters less than $2.0 \mathrm{~mm}$ and is chiefly responsible for water and nutrient uptake (Pregitzer et al. 2002; Wang et al. 2017) these are referred to as "feeder roots" in the older literature (Ford 1952; Soong 1976). The fine root biomass (FRB) and fine root length density (FRLD) are the most common root traits measured in agronomical and ecological root studies (Hendrick and Pregitzer 1993). Specific root length (SRL), calculated as the ratio of root length to dry biomass and fine root diameter (FRD), are generally used as proxies for potential fine root growth (Espeleta and Donovan 2002; Wang et al. 2014) and to characterize the trade-off in root construction at a community level (Roumet et al. 2016); Quite a few studies have been carried out on the evaluation of fine root traits of rubber trees in field conditions (Devakumar et al. 1999; Jessy et al. 2010; Jessy et al. 2013; Soong 1976; Maeght et al. 2015). However, there is a need for more study of the potential for manipulating young rubber tree root systems through intercrop interactions to improve their drought resistance.

In a field study, Jessy et al. (2010) found higher FRLD of rubber trees in the top seven centimeters of soil under drought conditions and with lower soil fertility in the surface layer. Similarly the FRB of rubber trees in the top 0.15$\mathrm{m}$ soil layer was higher in a rainfed plot than in an irrigated plot (Devakumar et al. 1999) with a more uniform vertical root distribution in the top 0.45 -m soil layer in the irrigated plots than in the rainfed plots. Jessy et al. (2013) reported higher fine root production, turnover and carbon and nutrient recycling through fine roots when the trees were subject to water stress and nutrient stress. Maeght et al. (2015) by monitoring the root system up to a depth of $4.5 \mathrm{~m}$, showed that deep roots of rubber trees only extended when rainfall became scarce, which was interpreted as an adaptive response of trees to water stress. These results suggest that rubber tree root systems would have enough plasticity to develop deep roots in response to the competition for resources. However, beneficial compensatory deep root growth may not be possible if the local soil is not deep enough or if the intensity and nature of the intercrop interactions hamper tree root growth (Schroth 1999).

This study evaluated the effect of a legume (Pueraria phaseoloides) intercrop and a grass (Vetiveria zizanoides) intercrop on the fine root traits of young rubber trees. We tested four hypotheses: (1) both intercrops modify the rubber tree root traits and distribution through the soil profile; (2) the legume intercrop promotes deep root development in response to increased water stress and nitrogen facilitation; (3) the grass intercrop promotes a shallow tree root system in response to both strong water and nutrient competition; and (4) The effects of intercrops on the trees will depend on the soil depth.

\section{Materials and methods}

\subsection{Site}

The experimental field was on a gentle slope of 5\%, near in Ban Non Tun Village in the Phra Yuen district in Northeastern Thailand (Isan) $\left(16^{\circ} 28^{\prime} \mathrm{N}, 102^{\circ} 45^{\prime} \mathrm{E}\right)$. This is one of the driest regions in Thailand. The average annual rainfall of $1400 \mathrm{~mm} /$ year over the study period (2007-2010), fell mainly between May and October. The mean temperature was $30^{\circ} \mathrm{C}$ from March to October and $25{ }^{\circ} \mathrm{C}$ from November to February. Figure 1 shows the relationship between precipitation $(\mathrm{P})$ and the reference evapotranspiration (ET0) calculated using the Penman-Monteith equation. The dry seasons with a negative water budget $(\mathrm{P}-\mathrm{ET} 0<0)$ generally occurred between October and April. However, in 2010, the dry season was particularly long as it continued until July.

The soil was classified in the Paleustults (US Soil Taxonomy system). It comprised a highly permeable sandy loam top soil layer, which was $0.6 \mathrm{~m}$ thick at the top of the toposequence and $1.3 \mathrm{~m}$ thick at the bottom, overlying a quasi-impermeable clay layer $0.20 \mathrm{~m}$ thick at the top of the toposequence and $0.70 \mathrm{~m}$ thick at the bottom. The bedrock
Fig. 1 Photos of a rubber tree row with Pueraria phaseoloides (left) and Vetiveria zizanoides (right) as intercrops in the 7-m wide interrows on both sides of the tree row. The intercrops were cut every 3 months and the residues spread on the soil surface. The intercrops regrew naturally after each cut. The trees were 4 years in the photo
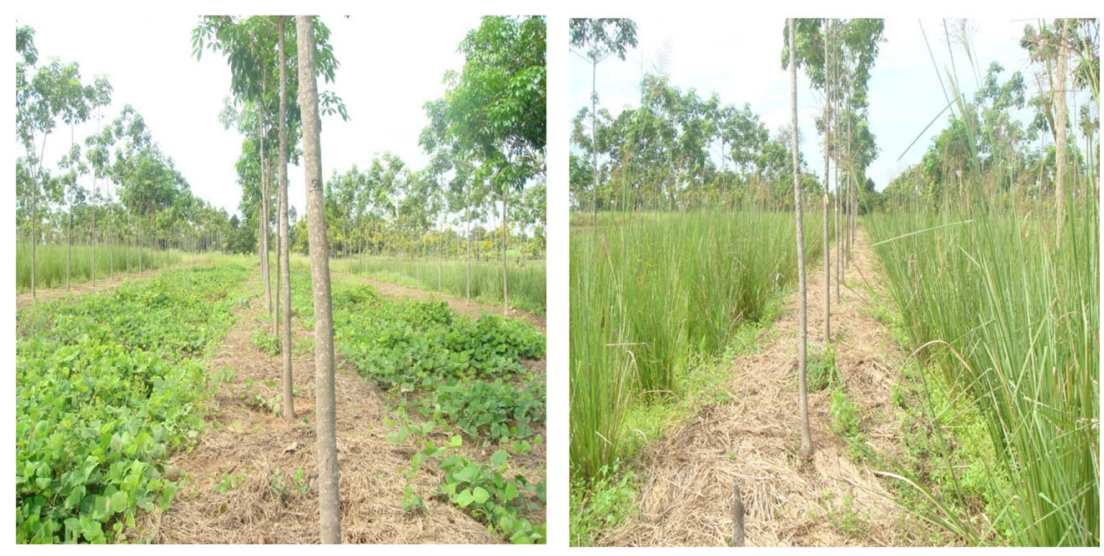
was highly weathered and fractured sandstone. The sandy soil layer was slightly acidic (pH 5 to 6), with low CEC ranging from 2 to $3 \mathrm{cmol} / \mathrm{kg}$ and low soil organic matter (SOM) ranging from 0.3 to $0.5 \%$. The maximum soil water storage capacity at the top of the toposequence (from the soil surface to the bedrock) was $248 \mathrm{~mm}$ and increased more than threefold at the bottom of toposequence to $676 \mathrm{~mm}$ (Clermont-Dauphin et al. 2016).

\subsection{Experimental design and crop management}

The experiment was set-up in 2007 in a 3-year-old rubber plantation and continued for 4 years (2007-2010). The trees were still in juvenile phase at the end of the experiment. Three systems were tested: rubber tree alone (Control), rubber trees with Pueraria phaseoloides intercrop (Pueraria), and rubber trees with Vetiveria zizanoides intercrop (Vetiveria). They were grouped into blocks with one plot per system. One block was at the top of toposequence and the other at the bottom. The trees (clone RRIM 600) were planted at a spacing of $7 \mathrm{~m}$ between rows and $3 \mathrm{~m}$ between trees within each row, giving a tree density of about 476 trees ha ${ }^{-1}$. The intercrops were planted in the interrows (Fig. 2). The plot sizes were $21 \mathrm{~m} \times$ $69 \mathrm{~m}$ and each plot had three rows of 23 trees, two interrows, and a half interrow on each side. The intercrops took one rainy season to cover the entire area. From the second year of the experiment, they were cut every 3 months and their residues spread on the soil surface in place. The average dry biomass of the legume residues was $8 \mathrm{t} \mathrm{ha}^{-1}$ year ${ }^{-1}$, while that of the grass was $16 \mathrm{t} \mathrm{ha}^{-1}$ year $^{-1}$. Except after the severe dry season of 2010 where most of the intercrops died, the intercrops regrew naturally after each cut. The Control plots were weeded by hand every 3 months. No manure was applied on the plots. Chemical fertilizer was applied as recommended for pure stands of immature rubber tree plantations. The NPK dose of 80-20-40 $\mathrm{g}$ tree $^{-1}$ (equivalent to 38-9.5-19 $\mathrm{kg} \mathrm{ha}^{-1}$ year $^{-1}$ ) was split into two applications in July and September and applied inside a 1-m diameter circle around each tree and incorporated into the top 5-7 cm of the soil. No fertilizer was applied in the interrows. Until the end of the monitoring period, the tree canopy remained sparse and did not compete with the intercrops for light.

These intercrops are not common in the rubber tree plantation of the study region. Most farmers cultivate pure stands of rubber trees or use cassava as intercrop. Pueraria is more common in rubber plantations in humid areas of the IvoryCoast where it gradually dies as the tree canopy closes (Delabarre 1998). Vetiveria is more generally used as hedge to control soil erosion on steep slopes. Here, contrary to the usual practice, the intercrops were cut to reduce their competition with the trees for resources during the dry season, and provide mulch residues to improve the soil nutrient recycling, water conservation and reduce soil erosion. Pueraria might also improve the young tree nitrogen uptake through atmospheric nitrogen fixation. The intercrops were introduced only when the trees were 3 years old to prevent the risk of tree mortality induced by excessive competition for water by the intercrops in a newly established plantation.

\subsection{Parameters measured}

\subsubsection{Tree girth, and $\mathrm{N}, \mathrm{P}$, and $\mathrm{K}$ concentration in leaves}

The girth of the 23 trees in the central tree row of each plot was measured from April 2007 to January 2011 every 15 days, with a measuring tape at $1.50 \mathrm{~m}$ above the soil surface. N, P, and K concentrations in the tree leaves were analyzed on three composite samples collected in June 2009 from each plot. Each composite sample comprised 23 fully expanded leaves. One leaf was collected from the top of a branch of each of the 23 trees in the central row of the plot. After being dried $\left(70{ }^{\circ} \mathrm{C}, 72 \mathrm{~h}\right)$, and ground $(<0.2 \mathrm{~mm})$, the samples were analyzed for $\mathrm{N}, \mathrm{P}$, and $\mathrm{K}$ contents. $\mathrm{N}$ was measured by the Kjeldahl digestion method. $\mathrm{P}$ and $\mathrm{K}$ were measured by digestion with $\mathrm{HClO}_{4}$.
Fig. 2 Average daily rainfall and reference evapotranspiration $\left(\mathrm{ET}_{0}, \mathrm{FAO}\right.$ Penman-Monteith method) in the study site over the monitoring period (2007-2011)
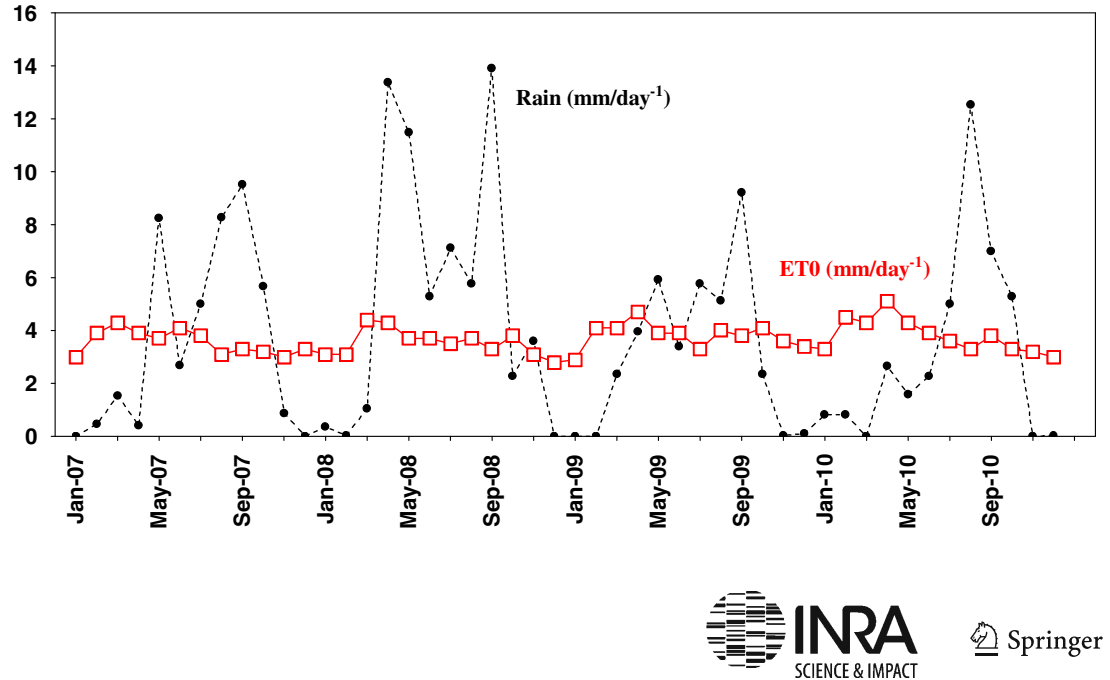


\subsubsection{Predawn leaf water potential and tree mortality}

The tree predawn leaf water potential $(\Psi p)$ was measured in the three plots at the top and bottom of the toposequence from April 2007 to January 2011 every 15 days. All the $\Psi$ p measurements were carried out for two fully expanded leaves in sunny positions on three trees selected from the central row of each plot, between 4:00 and 6:30, using a pressure chamber (PMS 1000, PMS Instrument Company, Corwallis, Oregon, USA). Trees with at least 75\% necrotic branches were classified as dead. They were counted every year at the end of the dry season.

\subsubsection{Soil water profiles}

Soil water content (SWC) was measured fortnightly from March 2008 to June 2010 using capacitive soil moisture probes (Sentek, EnvironScan, Sentek sensor technologies, Stepney SA, Australia). In each plot at the top and bottom of the toposequence, three access tubes were installed in a tree row and three in the adjacent interrow. The tubes within the row were $1 \mathrm{~m}$ away from the nearest tree, and the corresponding tube in the interrow was $2 \mathrm{~m}$ away from the tree row, opposite this tree. The soil moisture probes went down to $2 \mathrm{~m}$, so, at the top of the toposequence, it was necessary to drill into the bedrock to install the access tubes. SWC was measured every $0.2 \mathrm{~m}$ from $0.1 \mathrm{~m}$ down to $1.4 \mathrm{~m}$ deep at the bottom of the toposequence and to $0.80 \mathrm{~m}$ deep at the top of the toposequence. Each access tube was calibrated gravimetrically in situ for various soil layers in the dry and rainy seasons, to assess the dry and nearly saturated soil water content accurately.

\subsubsection{Length and biomass of fine roots}

In June 2010, fine root samples were collected using a cylindrical root auger ( $4 \mathrm{~cm}$ in diameter, $0.1 \mathrm{~L}$ in volume), from 12 positions around one tree per plot, at the top and bottom of the toposequence. In each plot, the selected tree was representative in size and vigor for the trees of the whole plot. Of the 12 samples, six were from within a row (three on each side of the tree), at a distance of $1 \mathrm{~m}$ from the trunk, and six were from the interrow (three on each side of the tree) at a distance of $2 \mathrm{~m}$ from the trunk. At each point, undisturbed soil cores were collected at $0.10 \mathrm{~m}$ intervals down to $0.80-0.85 \mathrm{~m}$ deep at the top of the toposequence and down to $1.40-1.45 \mathrm{~m}$ at the bottom, corresponding to the average bedrock depth at the top and bottom of the toposequence. Within 3 days, all roots were sorted from the soil samples using a $0.5-\mathrm{mm}$ mesh size double sieve and then washed. Coarse and fine roots were separated on basis of their diameter, with $2 \mathrm{~mm}$ as the criterion. The fine roots were oven dried at $65^{\circ} \mathrm{C}$ for $48 \mathrm{~h}$ and weighed to calculate their dry biomass. Root lengths and diameters were measured by scanning according to the procedure described by Pierret et al. (2013). Fine root length density (FRLD) was calculated as the total fine root length divided by the corresponding soil volume. Specific root length (SRL) was calculated by dividing the total fine root length by the root dry biomass. Since the intercrops were completely dead when the roots were sampled, we assumed that most of the roots sampled were from the rubber trees. Rubber tree fine roots are usually pale yellowish in color and unsuberized (Soong 1976), and, therefore, easy to distinguish from Pueraria fine roots which are rather whitish and thinner and from those of Vetiveria which are rather rigid and tortuous.

\subsection{Data analysis}

The data was analyzed using the STATISTICA package. The experimental design was characterized as having a topographic position (top or bottom) and cropping system (Control, Pueraria or Vetiveria) as independent variables. In each plot, the 23 trees measured for trunk girth were considered as replicates for the girth $(N=23)$. Three composite leaf samples were considered as replicates for nutrient concentration measurements $(\mathrm{N}=3)$ and three trees as replicates for $\Psi \mathrm{p}$ measurements $(N=3)$. The average soil water content $(\mathrm{SWC})$ at a given depth was calculated by pooling the six measurements in the rows and interrows of each plot $(N=6)$. The average FRLD at a given soil depth was based on 12 samples collected from the rows and interrows of each plot $(N=12)$. Each variable was checked for normality using the chi-square test. Since the FRLD data were not normally distributed, they were analyzed using non-parametric Kruskal-Wallis test to compare the effect of the independent variables at each soil depth. The other results were normally distributed analyzed using twoway ANOVA with the independent variables as the factors. The probability level used to determine significance was $P<0.05$. Where appropriate, mean values were compared using the Newman-Keuls test at the 5\% level.

Data availability statement The datasets analyzed during the current study are available from the corresponding author on reasonable request.

\section{Results and discussion}

\subsection{Effects of the intercrop species on the rubber tree nutrient status, growth and drought resistance}

\subsubsection{Rubber tree girth and N, P, and K concentrations in the leaves}

The girths were generally larger in the Pueraria plot than in the Vetiveria and the Control plots, and the difference between 
plots was much greater in the deep soil at bottom of the toposequence (Fig. 3). The girths in the Vetiveria plots were slightly smaller at the start of the monitoring period, but by the end the tree growth at bottom of the toposequence appeared to be recovering from the strong early competition from the grass. At the top and bottom of the toposequence, the intercrop resulted in higher $\mathrm{N}, \mathrm{P}$, and $\mathrm{K}$ concentration in the rubber tree leaves than in the Control plots. Tree leaf $\mathrm{N}$ and $\mathrm{K}$ concentration in the Pueraria plots was higher than in the Vetiveria plots, while the $\mathrm{P}$ concentration was similar. The $\mathrm{N}$ and $\mathrm{K}$ concentrations were lower at bottom of the toposequence than at the top (Table 1).

\subsubsection{Predawn leaf water potential $\left(\Psi_{\mathrm{p}}\right)$ of rubber tree leaves and tree mortality}

At the end of each dry season from March 2008 to March 2010, $\Psi$ p was significantly higher, indicating lower water stress in all plots at the bottom of the toposequence than in those at the top. $\Psi$ p was significantly higher in the intercrops than in the Control in two cases (1) in the rainy season, where the trees benefited from the mulch in the intercrop plots and were less affected by the short dry periods in this season, and (2) during the severe drought in June 2010 at the bottom of the toposequence (Table1). At the top of the toposequence, however, $\Psi \mathrm{p}$ was lower in the Pueraria plot than in the Control plot during the dry seasons. After the dry season 2010 , the tree mortality at the top of the toposequence was $5 \%$ in the Vetiveria plot, $22 \%$ in the Control plot, and $50 \%$ in the Pueraria plot. No trees died in the plots at the bottom of the toposequence (Table 1).

\subsubsection{Relationships between the variables}

The higher tree leaf $\mathrm{N}$ content observed in the Pueraria plot was probably related to the transfer of nitrogen, fixed by the legume, to the tree (Clermont-Dauphin et al. 2016). At bottom of toposequence, where water was not limiting, the higher nutrient availability significantly increased the tree girth in the Pueraria plot with respect to the Control. However, in the shallow soil at the top of toposequence, the increased water demand of the larger trees in the Pueraria plot increased the risk of tree mortality during severe drought. In the Vetiveria plots, the improved water and nutrient status did not result in higher girths than in the Control plots. The lower nutrient content of the tree leaves at the bottom of the toposequence than at the top may be related to the lower water stress and higher growth rate of the trees at the bottom, leading to dilution of nutrients in the higher tree biomass, as already shown by Lemaire and Gastal (1997) for annual crops.

\subsection{Root plasticity: effect of soil water content and tree plant nutritional status on the tree fine root traits}

\subsubsection{Soil water content}

The highest soil water content was in October at the end of the rainy seasons, and averaged 30 to $35 \%$, corresponding to saturation. During the dry seasons, the lowest soil water content was $10-15 \%$ in March, about $1 / 3$ of saturation. This agreed with the soil water budget calculated as the difference between rainfall and ET0 (Fig. 1). In the dry seasons in March 2009
Fig. 3 Girth at $150 \mathrm{~cm}$ in the different treatments over 4 years (2007-2011). Vertical bars are standard errors of the mean $(N=23)$

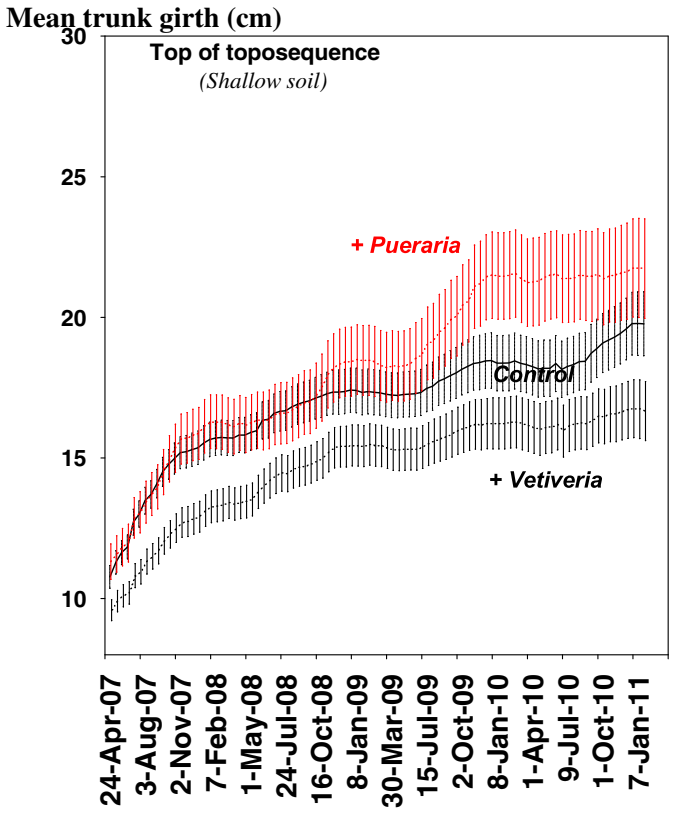

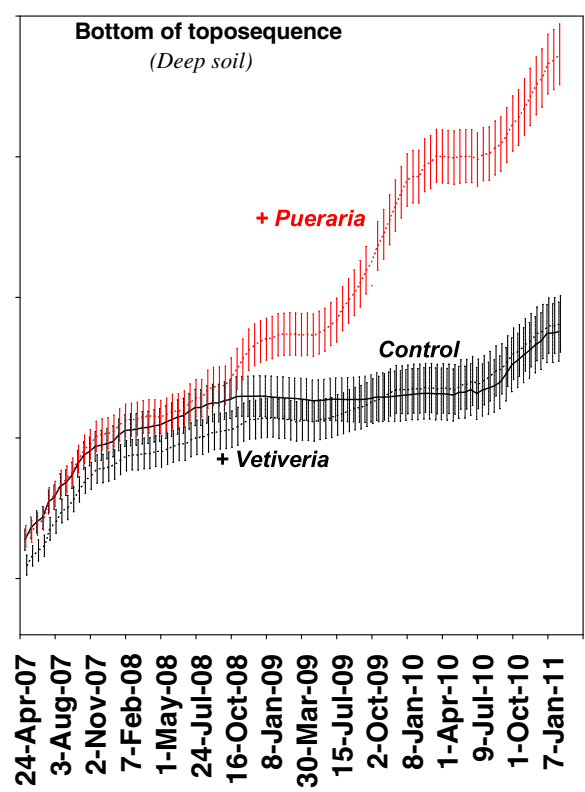

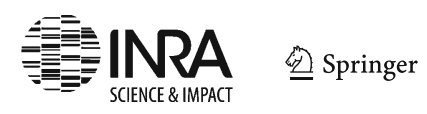


Table 1 Summary of indicators recorded from the trees. Means are calculated from: (1) $n=3$; (2) $n=6$ average of March 2008 and 2009; (3) $n=6$ average of Oct 2008, 2009, and 2010; (4) $n=6$; (5) $n=23$; (6) $n=108$, in $0-85$-cm soil layer at top of toposequence, and $n=180$, in 0 145-cm soil layer at bottom of toposequence. Different letters in the same line indicate significant difference at $P<0.05$ level according to Newman-Keuls test. FRLD $=$ fine root length density, $S R L=$ specific root length

\begin{tabular}{|c|c|c|c|c|c|c|}
\hline \multirow{2}{*}{$\begin{array}{l}\text { Plot position on the toposequence } \\
\text { Treatments }\end{array}$} & \multicolumn{3}{|c|}{ Top (shallow soil) } & \multicolumn{3}{|c|}{ Bottom (deep soil) } \\
\hline & Control & Pueraria & Vetiveria & Control & Pueraria & Vetiveria \\
\hline \multicolumn{7}{|l|}{ Leaf nutrient status in June 2009 (\%) } \\
\hline $\mathrm{N}(1)$ & $1.95 \mathrm{c}$ & $2.71 \mathrm{a}$ & $2.26 \mathrm{~b}$ & $1.53 \mathrm{~d}$ & $2.56 \mathrm{a}$ & $1.92 \mathrm{c}$ \\
\hline $\mathrm{P}(1)$ & $0.15 \mathrm{c}$ & $0.19 \mathrm{~b}$ & $0.19 \mathrm{~b}$ & $0.16 \mathrm{~b}$ & $0.20 \mathrm{a}$ & $0.19 \mathrm{a}$ \\
\hline $\mathrm{K}(1)$ & $0.49 \mathrm{c}$ & $0.61 \mathrm{a}$ & $0.56 \mathrm{~b}$ & $0.45 \mathrm{c}$ & $0.53 \mathrm{c}$ & $0.47 \mathrm{c}$ \\
\hline \multicolumn{7}{|l|}{ Leaf water potential in predawn $(\mathrm{MPa})$} \\
\hline$\Psi p$ March (2) (end dry season 2008, 2009) & $-0.52 b$ & $-0.58 \mathrm{c}$ & $-0.40 \mathrm{~b}$ & $-0.36 \mathrm{a}$ & $-0.35 \mathrm{a}$ & $-0.34 \mathrm{a}$ \\
\hline$\Psi p$ October (3) (end rainy season 2008,2009 ) & $-0.26 b$ & $-0.24 \mathrm{a}$ & $-0.22 \mathrm{a}$ & $-0.32 \mathrm{c}$ & $-0.27 b$ & $-0.21 \mathrm{a}$ \\
\hline$\Psi p$ June (4) (end dry season 2010) & $-0.70 b$ & $-0.87 \mathrm{c}$ & $0.79 \mathrm{bc}$ & $-0.75 b$ & $-0.52 \mathrm{a}$ & $-0.54 \mathrm{a}$ \\
\hline$\%$ dead trees in $2010(5)$ & 22 & 50 & 5 & 0 & 0 & 0 \\
\hline Girth (cm) in 2010 (5) & $19 \mathrm{~b}$ & $20 \mathrm{~b}$ & $16 \mathrm{~b}$ & $17 \mathrm{~b}$ & $25 \mathrm{a}$ & $18 \mathrm{~b}$ \\
\hline \multicolumn{7}{|l|}{ Root traits in June 2010} \\
\hline $\operatorname{FRLD}\left(\mathrm{cm} \mathrm{cm}^{-3}\right)(6)$ & $0.84 \mathrm{~b}$ & $0.75 \mathrm{~b}$ & $0.67 \mathrm{~b}$ & $0.73 \mathrm{~b}$ & $0.92 \mathrm{a}$ & $0.60 \mathrm{~b}$ \\
\hline Fine root biomass $\left(\mathrm{g} / \mathrm{dm}^{-3}\right)(6)$ & $0.33 \mathrm{~b}$ & $0.40 \mathrm{~b}$ & $0.38 \mathrm{~b}$ & $0.39 \mathrm{~b}$ & $0.74 \mathrm{a}$ & $0.31 \mathrm{~b}$ \\
\hline $\operatorname{SRL}\left(\mathrm{m} \mathrm{g}^{-1}\right)(6)$ & $29 \mathrm{~b}$ & $19 \mathrm{~b}$ & $25 \mathrm{~b}$ & $33 \mathrm{a}$ & $14 \mathrm{bc}$ & $22 \mathrm{~b}$ \\
\hline Root diameter (mm) (6) & $0.37 \mathrm{~b}$ & $0.38 \mathrm{~b}$ & $0.37 \mathrm{~b}$ & $0.36 \mathrm{~b}$ & $0.54 \mathrm{a}$ & $0.42 \mathrm{~b}$ \\
\hline
\end{tabular}

and 2010, SWC at a soil depth of $110 \mathrm{~cm}$ was significantly lower in the Pueraria plots at the bottom of the toposequence than in the Control and Vetiveria plots (Fig. 4).

\subsubsection{Fine root length density}

At the top of the toposequence, the fine root length density (FRLD) of the rubber trees averaged over the entire soil profile (from 0 to $85 \mathrm{~cm}$ ) was $0.75 \pm 0.08 \mathrm{~cm} \mathrm{~cm}^{-3}$ and was not significantly different between plots (Table 1). For all plots, the FRLD was highest in the $0-25-\mathrm{cm}$ soil layer, representing $70 \%$ of the total FRLD in the Control plot, $68 \%$ in the Vetiveria plots and 53\% in the Pueraria plot (Fig. 4). FRLD of rubber tree in Pueraria plot increased below $50 \mathrm{~cm}$ and became significantly higher than in the Control and Vetiveria plot below $70 \mathrm{~cm}$. At the bottom of the toposequence, the FRLD of the rubber trees averaged over the entire soil profile (from 0 to $145 \mathrm{~cm}$ ) was significantly higher in Pueraria at $0.92 \pm 0.006 \mathrm{~cm} \mathrm{~cm}^{-3}$ (Table 1). Figure 5 shows that the vertical FRLD distribution was more uniform in Pueraria plot than in the control, and less uniform in the Vetiveria plot. Fifty-four of the total FRLD in the Vetiveria plot was in the $0-25-\mathrm{cm}$ soil layer, whereas only $28 \%$ was in this soil layer in the Pueraria plot.

\subsubsection{Fine root biomass, specific root length, and fine root diameter}

At the top of the toposequence, the fine root biomass (FRB), the specific root length (SRL) and the fine root diameter (FRD) of the rubber trees were not significantly different between plots (Table 1). However, at the bottom of the toposequence, the Pueraria plot had the highest FRB and FRD and the lowest SRL, less than half that of the Control plot (Table 1). There was no significant difference between top and bottom of toposequence for FRB, SRL and FRD.

\subsubsection{Relationships between rubber tree root traits, nutrient limitations, and soil water content}

Our results agreed with other studies showing that water limitation encouraged vertical root extension whereas nutrient limitation encouraged lateral root extension (Jessy et al. 2010; Jessy et al. 2013; Wang et al. 2017). At the top of the toposequence, where the water stress was particularly high (Table 1), the combination of competition for water and $\mathrm{N}$ facilitation caused in increase in fine roots at depth in the Pueraria plot (Fig. 5). However, in the Vetiveria plot where tree growth was slower, the fine roots mainly grew in the top soil layers. As found for a peach tree/grass cropping system, a 
large reduction in plant growth, due to the intercrop, may not leave the roots system with enough carbon to invest in deep root growth (Forey et al. 2017). At the bottom of the toposequence, root plasticity was also observed with the trees in Vetiveria plot having the strongest variation of FRLD with soil depth, probably as an effect of low soil nutrient availability (Fig. 5). The higher nutrient availability with the $\mathrm{N}$ fixing Pueraria intercrop reduced the need for explorative fine roots and accounted for the relatively low SRL, in agreement with other studies (Olsthoorn et al. 1991; Ostonen et al. 2007; Wang et al. 2017). FRLD and SRL were similar to those for mature rubber trees grown in field conditions of northeast Thailand (Maeght et al. 2015).

If the total biomass is optimally partitioned, more carbon should be allocated to root growth than to leaf and stem growth when water availability decreases, resulting in either a larger FRB to aboveground biomass ratio or a higher fine root turnover or both (Poorter et al. 2012). Our results showed this effect when comparing the tree behavior in Pueraria plots at the top and bottom of the toposequence. At the top of the toposequence, where water stress was high, the tree trunk at the end of the monitoring period was $60 \%$ smaller than that in the corresponding plot at the bottom of the toposequence (Fig. 3) while the fine root biomass was reduced by $45 \%$ only (Table 1 ).

\subsection{Measured root traits do not completely explain how the intercrops improved the drought resistance}

At bottom of the toposequence, during the severe dry period of June 2010, the water depletion at soil depths of 70 to $145 \mathrm{~cm}$ was higher in the intercrop plots than in the Control (Fig. 4) this was coupled with a lower $\Psi$ p in the intercrop plots (Table 1) suggesting that the water depletion in deeper soil layers was due to increased uptake by the trees and not the intercrops. Therefore, it could be concluded that the competition from the intercrop favored vertical root exploration and water uptake from the deep soil layers. This interpretation is supported by the higher FRLD in deep layers in the Pueraria plot.

Although this interpretation fits the Pueraria intercrop, it is not a full explanation for the Vetiveria intercrop. Although the soil water content in the deep layers was reduced, this was not associated with a higher FRLD for the trees. The must, therefore, be processes other than the measured changes in morphological characteristics of the fine roots to explain the improved tree water status during the 2010 dry season in the Vetiveria plots. One of these processes might be related to the stimulation of arbuscular mycorrhizal fungi (AMF)
Fig. 4 Soil water content (\%) along the soil profile at bottom of toposequence at end of rainy season 2008 (a) and 2009 (c) and end of dry season 2009 (b), and 2010 (d). Horizontal bars denote standard errors. Values followed by the same letter within a soil depth are not significantly different $(P<0.01$, NewmanKeuls test)
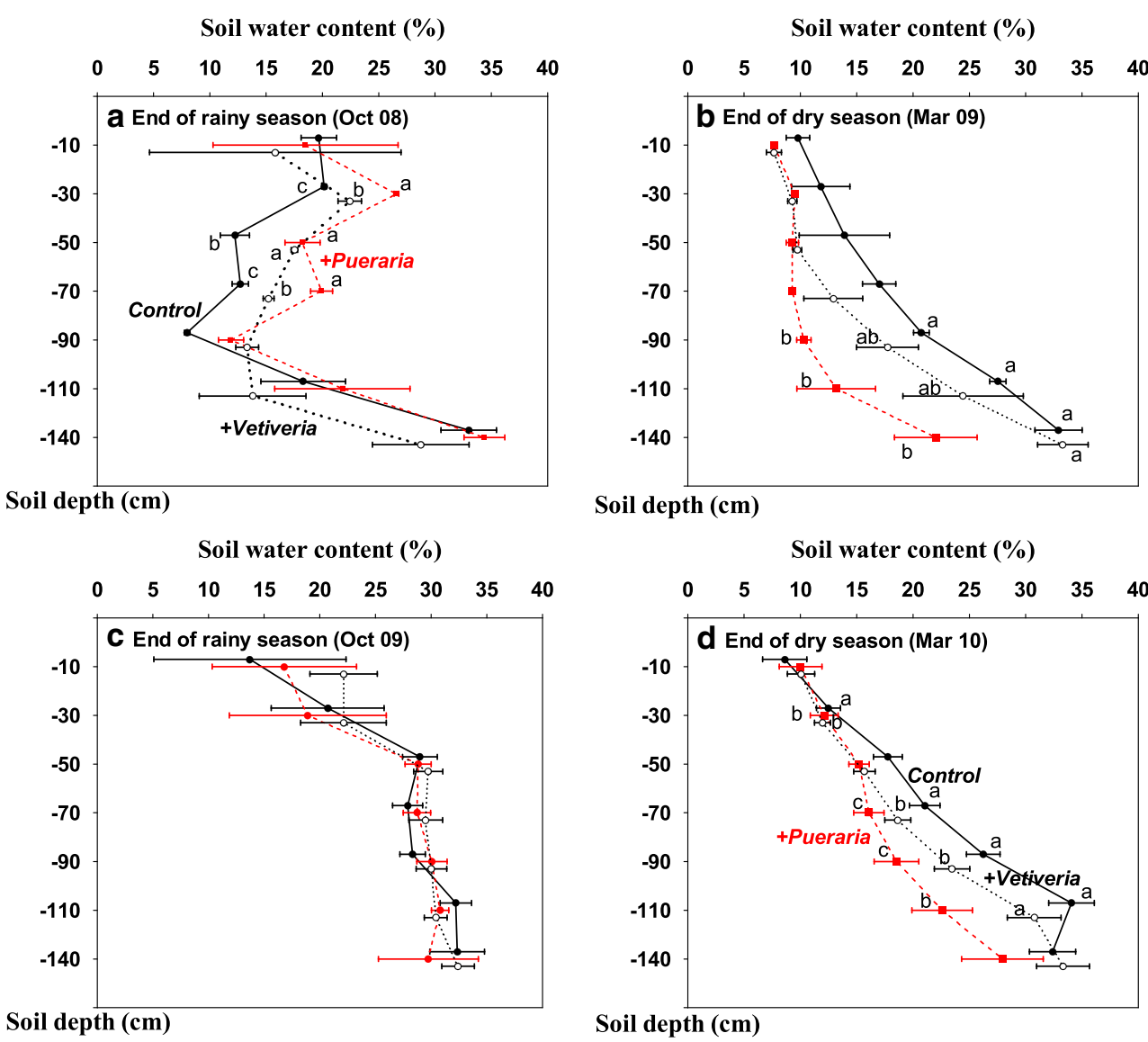

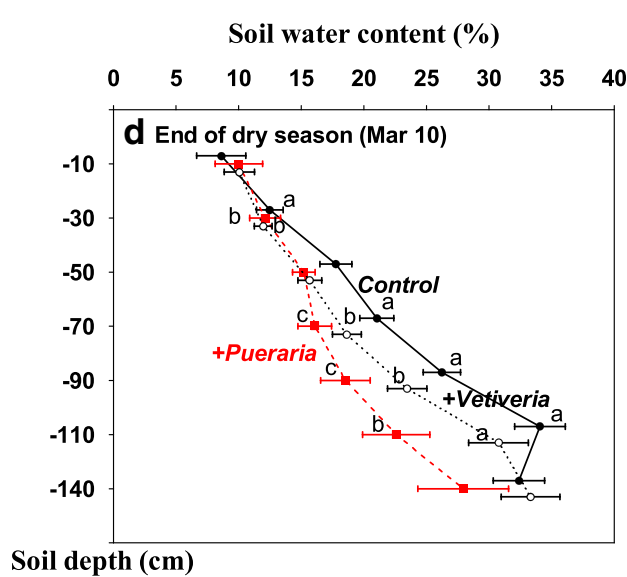


Fig. 5 Mean fine root length density (FRLD, $\mathrm{cm} / \mathrm{cm}^{3}$ ) of rubber tree along the soil profile at top (a) and bottom (b) of toposequence during the dry period of June 2010. Horizontal bars denote standard errors of the means. Values followed by the same letter within a soil depth are not significantly different $(P<$ 0.01 , Newman-Keuls test)
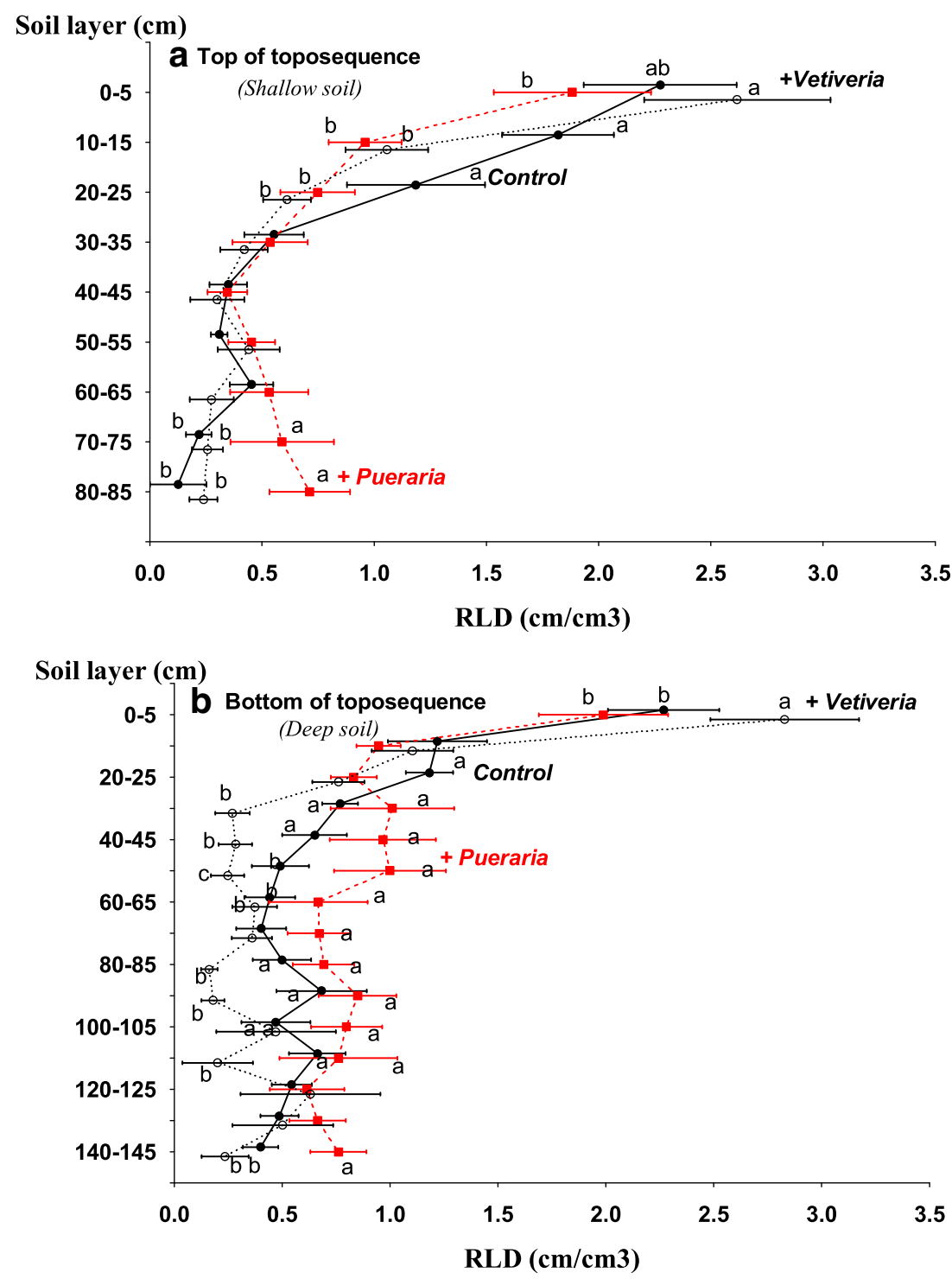

providing more efficient access to water from deep soil layers. This hypothesis is supported by various recent studies (Verzeaux et al. 2017; Wang et al. 2017).

The root profiles may be analyzed in light of the concept of "critical FRLD for water capture". The critical water capture was defined as the minimum FRLD for full water capture and the average value of $1 \mathrm{~cm} \mathrm{~cm}^{-3}$ was proposed for it (Barraclough 1984; Brown et al. 1989). According to this critical value, rubber tree FRLDs recorded at bottom of toposequence, was too low for full water capture below the soil depth of $30 \mathrm{~cm}$ in Vetiveria and Control plots, and $50 \mathrm{~cm}$ in Pueraria plot. The same analysis at top of the toposequence indicated that full water capture was limited to the first $15 \mathrm{~cm}$ in Pueraria and Vetiveria plots and $25 \mathrm{~cm}$ in Control plot. As pointed out by White et al. (2013), whereas critical FRLD is used as a key parameter for modeling plant water uptake (King et al. 2003), validation efforts using a range of crop species and soil types should be continued to completely rely on it to analyze field observations.

\section{Conclusions}

Our field study confirmed for the first time that various traits of the root system of young rubber trees were modified by intercrop interactions (hypothesis 1). The FRLD of the trees showed adaptive responses to water stress when the intercrop was the legume Pueraria phaseoloides. This was particularly clear on shallow soils with limited available water and was expressed by an increase FRLD in deep soil layers (hypothesis 2). However, because of the increased water demand associated with the increased nutrient availability and consequent growth, tree mortality was particularly high in the legume 
intercrop plots on shallow soil (hypothesis 4). When the intercrop was Vetiveria zizanoides, the low nutrient availability and/or low growth of the trees did not allow the rubber tree root extend the root system vertically (hypothesis 3 ) and Vetiveria intercropping was associated with shallow root systems, low tree growth, low water demand, and high drought resistance. At the bottom of the toposequence, rubber trees growing in the Pueraria plot had the highest FRB, the lowest SRL (hypothesis 2, 4), and were most resistant to drought.

There are some practical lessons for the expansion of Hevea/intercrop systems into the study area. (1) Both intercrops can be recommended for modifying the tree root system functioning to increase drought resistance during the juvenile phase of the trees. Of course, they will gradually disappear with the tree canopy closure (2) Pueraria phaseoloides should, however, be avoided in shallow soils less than $75 \mathrm{~cm}$ depth, as it increases the water demand and the risks of tree mortality. (3) Vetiveria zizanoides should be planted with a greater distance from the trees and with an increase in the grass cutting frequency. This will reduce the risk of competition from the grass and leave the trees with enough carbon to invest in deep root when the water supply becomes limiting. (4) Even with the management system used in this study, in deep soils more than $100-\mathrm{cm}$ depth, trees with Vetiveria intercrop may recover from the strong early competition by the intercrop before the end of the juvenile phase of the plantation.

Acknowledgments We would like to thank many people for their contribution to the field data collection and processing, in particular, Vincent Cheylan (IRD), Weerawut Yotjamrut, and Nitjaporn Koonklang (LDD).

\section{Compliance with ethical standards}

Conflict of interest The authors declare that they have no conflict of interest.

\section{References}

Barraclough P (1984) The growth and activity of winter wheat roots in the field: root growth of high-yielding crops in relation to shoot growth. J Agric Sci 103(2):439-442. https://doi.org/10.1017/ S0021859600047419

Broughton WJ (1977) Effects of various covers on soil fertility under Hevea brasiliensis and on growth of the tree. Agro-Ecosystems 3: $147-170$

Brown SC, Gregory PJ, Cooper PJM, Keatinge JDH (1989) Root and shoot growth and water use of chickpea (Cicer arietinum) grown in dryland conditions: effect of sowing date and genotype. J Agric Sci (Camb) 113:41-49

Clermont-Dauphin C, Suvannang N, Pongwichian P, Cheylan V, Hammecker C, Harmmand JM (2016) Dinitrogen fixation by the legume cover crop Pueraria phaseoloides and transfer of fixed $\mathrm{N}$ to Hevea brasiliensis - impact on tree growth and vulnerability to drought. Agric Ecosyst Environ 217:79-88. https://doi.org/10. 1016/j.agee.2015.11.002
Crook MJ, Ennos AR (1998) The increase in anchorage with tree size of the tropical tap rooted tree Mallotus wrayi, King (Euphorbiaceae). Ann Bot 82:291-296. https://doi.org/10.1006/anbo.1998.0678

Delabarre M (1998) Rapport final: fonctionnement des cultures associées à base d'hévéa, Troisième programme STD, Numéro de contrat TS3-CT92-148, Cirad, pp 1992-1995

Devakumar AS, Prakash PG, Sathik MBM, Jacob J (1999) Drought alters the canopy architecture and micro-climate of Hevea brasiliensis trees. Trees 13:161-167. https://doi.org/10.1007/PL00009747

Espeleta JF, Donovan LA (2002) Fine root demography and morphology in response to soil resources availability among xeric and mesic sandhill tree species. Funct Ecol 16:113-121. https://doi.org/10. 1046/j.0269-8463.2001.00590.x

Ford HW (1952) The distribution of feeder roots of orange and grapefruit trees on rough lemon rootstock. Citrus Mag 14:22-23

Forey O, Temani F, Wery J et al (2017) Effect of combined deficit irrigation and grass competition at plantation on peach tree root distribution. Eur J Agron 91:16-24. https://doi.org/10.1016/j.eja.2017.08. 008

Hendrick RL, Pregitzer KS (1993) The dynamics of fine root length, biomass, and nitrogen content in two northern hardwood ecosystems. Can J For Res 23:2507-2520. https://doi.org/10.1139/x93-312

Jessy MD, Prasannakumari P, Nair RB, Vijayakumar KR, Nair NU (2010) Influence of soil moisture and nutrient status on fine root dynamics of rubber trees (Hevea brasiliensis). J Plant Crop 38:9296

Jessy MD, Prasannakumari P, Abraham J (2013) Carbon and nutrient cycling through fine roots in rubber (Hevea Brasiliensis) plantations in India. Exp Agric 49(4):556-573. https://doi.org/10.1017/ S0014479713000203

Kaye JP, Quemada M (2017) Using cover crops to mitigate and adapt to climate change. A review. Agron Sustain Dev 37:4. https://doi.org/ 10.1007/s13593-016-0410-x

King JA, Gay A, Sylvester-Bradley R, Bingham I, Foulkes M, Gregory P, Robinson D (2003) Modelling cereal root systems for water and nitrogen capture: towards an economic optimum. Ann Bot 91: 383-390. https://doi.org/10.1093/aob/mcg033

Lemaire G, Gastal F (1997) N Uptake and distribution in plant canopies. Diagnosis of the nitrogen status in crops. In: G. Lemaire (ed) Springler Verlag, New-York, pp 3-44

Maeght JL, Gonkhamdee S, Clément C, Isarangkool Na Ayutthaya S, Stokes A, Pierret A (2015) Seasonal patterns of fine root production and turnover in a mature rubber tree (Hevea brasiliensis Müll. Arg.) stand-differentiation with soil depth and implications for soil carbon stocks. Front Plant Sci 6:1022. https://doi.org/10.3389/fpls.2015. 01022

Olsthoorn AFM, Keltjens WG, Van Baren B, Hopman MCG (1991) Influence of ammonium on fine root development and rhizosphere $\mathrm{pH}$ of Douglas-fir seedlings in sand. Plant Soil 133(1):75-81. https://doi.org/10.1007/BF00011901

Ostonen I, Püttsepp Ü, Biel C, Alberton O, Bakker MR, Lõhmus K, Majdi H, Metcalfe D, Olsthoorn AFM, Pronk A, Vanguelova E, Weih M, Brunner I (2007) Plant Biosystems 141 (3):426-442

Persson HA (1983) The distribution and productivity of fine roots in boreal forests. Plant Soil 71:87-10. https://doi.org/10.1007/ BF02182644

Pierret A, Gonkhamdee S, Jourdan C, Maeght JL (2013) IJ_Rhizo: an open-source software to measure scanned images of root samples. Plant Soil 373:531-539. https://doi.org/10.1007/s11104-013-1795-9

Poorter H, Niklas KJ, Reich PB, Oleksyn J, Poot P, Mommer L (2012) Biomass allocation to leaves, stems and roots: meta-analyses of interspecific variation and environmental control. New Phytol 193: 30-50. https://doi.org/10.1111/j.1469-8137.2011.03952.x

Pregitzer KS, DeForest JL, Burton AJ, Allen MF, Ruess RW, Hendrick RL (2002) Fine root architecture of nine North American trees. Ecol 
Monogr 72:293-309. https://doi.org/10.1890/00129615(2002)072[0293:FRAONN]2.0.CO;2

Roumet C, Birouste M, Picon-Cochard C, Ghestem M, Osman N, Vrignon-Brenas S, Kf C, Stokes A (2016) Root structure-function relationships in 74 species: evidence of a root economics spectrum related to carbon economy. New Phytol 210(3):815-826. https://doi. org/10.1111/nph.13828

Schenk HJ, Jackson RB (2002) Rooting depths, lateral root spreads and below-ground/above-ground allometries of plants in water-limited ecosystems. J Ecol 90:480-494. https://doi.org/10.1046/j.13652745.2002.00682.x

Schroth G (1999) A review of belowground interactions in agroforestry, focussing on mechanisms and management options. Agrofor Syst 43:5-34. https://doi.org/10.1023/a:1026443018920

Soong NK (1976) Feeder root development of Hevea brasiliensis in relation to clones and environment. J Rubber Res Inst Malays 24:283-298
Verzeaux J, Hirel B, Dubois F et al (2017) Agricultural practices to improve nitrogen use efficiency through the use of arbuscular mycorrhizae: Basic and agronomic aspects. Plant Sci 26:48-56. https://doi. org/10.1016/j.plantsci.2017.08.004

Wang BJ, Zhang W, Ahanbieke P, Gan YW, Xu WL, Li LH, Christie P, Li L (2014) Interspecific interactions alter root length density, root diameter and specific root length in jujube/wheat agroforestry systems. Agrofor Syst 88:835-850. https://doi.org/10.1007/s10457014-9729-y

Wang G, Liu F, Xue S (2017) Nitrogen addition enhanced water uptake by affecting fine root morphology and coarse root anatomy of Chinese pine seedlings. Plant Soil 418:177-189. https://doi.org/10. 1007/s11104-017-3283-0

White JP, George TS, Gregory PJ, Bengough AG, Hallet PD, McKenzie BM (2013) Matching roots to their environment. Ann Bot 112:207-222. https://doi.org/10.1093/aob/mct123 